\title{
Stock Valuation of Indonesia Pharmaceutical Company with COVID-19 Vaccination Development Prospects Amidst Pandemic Situation (Case Study of PT. Kalbe Farma, Tbk.)
}

\author{
Gideon Ericko Setiawan, and Erman Sumirat
}

\section{ABSTRACT}

\begin{abstract}
As one of the world's most populous countries with a fast-growing economy, Indonesia's market for pharmaceuticals has become very promising. COVID-19 pandemic that outbroken since early 2020 has brought a huge impact on the overall country condition while at the same time stimulate the growth of the pharmaceutical market as it is forecasted to grow at a CAGR of $6.3 \%$ between 2016 and 2021 according to IQVIA. This situation creates a reaction in the stock market especially of pharmaceutical companies that experienced an average increase of $67 \%$ since last year with its key driver of news regarding the distribution of Sinovac vaccine by some state-owned pharma companies as part of the national vaccination program. PT. Kalbe Farma, Tbk as one of the largest pharma companies in Indonesia is also accounting a positive growth over the years while also presented with bright prospects as a result of its strategic initiatives to collaborate with South Korea in developing COVID-19 vaccine and medication, named Genexine which is planned to be completed in Q3 2021. The possibility of success in this project might affect the company's stock performance since it would result in bigger profitability for the company. In order to help investors to make a decision in this situation, the intrinsic value of the company stock is required. Therefore, conducting absolute and relative valuation are believed to be important in order to find the intrinsic value. This study examined absolute valuation using FCFF model and relative valuation using P/E and EV/EBITDA for KLBF. Result of the valuation suggested that the current stock price of IDR 1,445 is overvalued. The intrinsic value calculated from FCFF model is IDR 1,397 and based on the relative valuation models are IDR 1,330 and IDR 1,233 for EV/EBITDA and P/E ratio, respectively.
\end{abstract}

Keywords: COVID-19, Kalbe Farma, pharmaceutical, stock valuation.
Submitted : August 22, 2021

Published : September 23, 2021

ISSN: $2507-1076$

DOI: $10.24018 /$ ejbmr.2021.6.5.1065

Gideon Ericko Setiawan

School of Business and Management Institute Technology of Bandung, Indonesia.

(e-mail: gideon_setiawan@ sbm-itb.ac.id) Erman Sumirat

School of Business and Management Institute Technology of Bandung, Indonesia.

*Corresponding Author

\section{INTRODUCTION}

The existence of COVID-19 pandemic as an extraordinary event affects various sectors, including the stock market. A study by Saragih and Nurhaida [1], confirmed the negative impact on this event towards the stock market performance. However, according to CSA Research Institute, the increasing demand of pharmaceuticals product create its positive sentiment for pharmaceutical stocks. This phenomenon was reflected in the extraordinary increase of these stocks prices, moreover after the announcement of the national vaccination program in Q2'20 that there is a positive correlation between movement in financial markets and financial news [2]. A study by Welley and Franky [3] carried out that there is a significant increase in the stock price of the pharma companies related to the national vaccination program, which are PT Indofarma (INAF) and PT Kimia Farma (KAEF). PT Kalbe Farma (KLBF) is one of the largest pharma companies with the biggest market capitalization in
Indonesia is currently presented with bright prospects as result of its strategic initiatives to co-develop COVID-19 vaccine and medication with South Korea in Q2'20, named Genexine which is planned to be completed in Q3'21 [4]. While starting in Q1'21, it is also a part of the national vaccination program distributor. However, unlike other pharmaceutical stocks that experienced a significant increase, KLBF price is relatively stable over the year as shown in Table I below.

TABLE I: Pharmaceutical STOCKS PRICE MOVEMENT STOCKS WITH ASTERISK (*) ARE CLOSELY RELATED TO VACCINE

\begin{tabular}{ccccccc}
\hline Company & Q2'20 & Q3'20 & Q4'20 & Q1'21 & $\begin{array}{c}21- \\
\text { Jun }\end{array}$ & $\begin{array}{c}\text { Avg. Price } \\
\text { Change (\%) }\end{array}$ \\
\hline KLBF & 1,460 & 1,550 & 1,480 & 1,570 & 1,480 & $0.5 \%$ \\
INAF* $^{*}$ & 985 & 2,860 & 4,030 & 2,460 & 2,580 & $49 \%$ \\
KAEF* $^{\prime}$ & 1,120 & 2,890 & 4,250 & 2,560 & 2,910 & $45 \%$ \\
PYFA & 610 & 815 & 975 & 930 & 1,200 & $19 \%$ \\
TSPC & 1,390 & 1,280 & 1,400 & 1,480 & 1,600 & $4 \%$ \\
DVLA & 2,180 & 2,520 & 2,420 & 2,370 & 2,470 & $3 \%$ \\
SIDO & 608 & 745 & 805 & 785 & 730 & $5 \%$ \\
\multicolumn{7}{c}{ Total Average } \\
\hline
\end{tabular}


According to Kahneman and Tversky's prospect theory [5], individuals make decisions based on perceived gains instead of perceived losses. In this case, KLBF price is relatively in the same price range, while the company is showing bright prospects and opportunities for its business in the upcoming months when the development of its COVID19 vaccine and medicine should be completed.

\section{LITERATURE REVIEW}

\section{A. Business Situation Analysis}

According to Porter [6], the essence of strategy formulation is coping with competition. This competition is not manifested only in the other players rather rooted in industry underlying economic and competitive forces [6]. The state of competition in an industry is determined by five basic forces known as the Porter's Five Forces (HBR). According to Barnes [7], financial ratios can be used to evaluate a business and a firm's performance. SWOT analysis determines what may assist the firm in accomplishing its objectives and understand what obstacles must be overcome [8].

A company can outperform rivals only if it can establish a difference that it can preserve [6]. KLBF is considered to possess some competitive advantage, which is strong brand value, advanced manufacturing technology, and distribution channel. Financial analysis involves comparing the firm's performance and evaluating trends in the firm's financial position over time [9]. Financial ratio analysis shows that KLBF is better than the industry average in terms of profitability, liquidity, and operational effectiveness while also produce consistent positive growth for the last five years.

SWOT analysis is a simple but powerful tool for sizing up an organization's resource capabilities and deficiencies, its market opportunities, and external threats to its futures [10]. SWOT analysis is also performed to conclude the position of KLBF as shown in Table II below.

TABLE II: SWOT ANALYSIS OF KLBF

\section{STRENGTHS}

\begin{tabular}{|c|c|}
\hline S1R & \\
\hline $\begin{array}{l}\text { 1. Strong brand value by owning } \\
\text { some of the most famous } \\
\text { healthcare products in its product } \\
\text { portfolio and the market leader for } \\
\text { Over the Counter products. } \\
\text { 2. Strong resources as it owns the } \\
\text { most advanced technology in } \\
\text { Indonesia for production as well } \\
\text { as R\&D. It is being involved in } \\
\text { the development of the vaccine. } \\
\text { 3. Robust distribution channels have } \\
\text { reached even the rural areas } \\
\text { across Indonesia, with } 1 \text { million } \\
\text { outlets coverage all over } \\
\text { Indonesia. }\end{array}$ & $\begin{array}{l}\text { 1. Highly dependable to the supplier } \\
\text { as more than } 90 \% \text { of medicine raw } \\
\text { materials are imported. } \\
\text { 2. Lack of innovation especially for } \\
\text { the herbal and supplemental } \\
\text { products that are currently become } \\
\text { the favorite. } \\
\text { 3. Tight competition especially with } \\
\text { the state-owned pharma } \\
\text { companies that generally have } \\
\text { better access for national health } \\
\text { projects. }\end{array}$ \\
\hline $\begin{array}{l}\text { OPPORTUNITIES } \\
\end{array}$ & THREATS \\
\hline $\begin{array}{l}\text { 1. Enormous population in } \\
\text { Indonesia with the continuous } \\
\text { growth of demand and } \\
\text { consumption for healthcare } \\
\text { products. } \\
\text { 2. Current development of vaccine } \\
\text { and medicine for COVID-19. The } \\
\text { success of this development will } \\
\text { lead to bright prospects for the }\end{array}$ & $\begin{array}{l}\text { 1. Risk towards the currency } \\
\text { exchange rate that is directly } \\
\text { implied in the process of acquiring } \\
\text { raw materials as the global } \\
\text { economic situation is facing high } \\
\text { uncertainty. } \\
\text { 2. Competition from foreign pharma } \\
\text { companies with relatively better } \\
\text { technology and resources. }\end{array}$ \\
\hline
\end{tabular}

\section{B. Valuation}

Calculation of intrinsic value may help the investor to identify mispriced securities to facilitate an investment decision [11]. This study conducted an absolute and relative valuation model in order to find the intrinsic value or the true, inherent, and essential value that is not depending upon accident, place, or person but is the same to everyone and everywhere as stated in Black's Law Dictionary [12]. Similar to Hampton [13] who defines the intrinsic value of a stock as the real worth of the stock, distinguished from the current market price of the stock.

Discounted Cash Flow (DCF) model is an intrinsic valuation model as it is valuing an asset-based upon its expected cash flows, adjusted for risk. Similar to Buffet that stated that intrinsic value can be acquired after taking the expected future cash flows and discount them back to the present value [17].

The value of assets in relative valuation is derived from the pricing of comparable assets or business by using variables such as earnings, book value, revenue, or cash flow as a comparison to the company which has a similar amount of asset or business to get the value of each company within their industry [17]. Brown also stated that relative valuation implicitly contends that it is possible to determine the value of an economic entity by comparing it to similar entities on the basis of several ratios that compare its stock price to relevant variables that affect a stock's value [18].

According to Zelazowski [19] multiples of P/E ratio can be used to properly reflect the main factors determining the value of the enterprise. As Pandey and Sehgal [20] study carried out that multiple $\mathrm{P} / \mathrm{E}$ is the best approach for equity valuation. Zelazowski [19] study also carried out that when dealing with different structures of business financing, the application of EV/EBITDA is recommended. Enterprise multiple is determined by the tax rate, depreciation, and amortization, reinvestment requirements, cost of capital, and expected growth [21]. The result of these valuation models will be complimenting each other and resulted in the conclusion of whether the current price of KLBF is undervalued or overvalued. A study from Persson and Stahlberg [22] carried out successful findings to determine undervalued stocks by using EV/EBITDA multiple and P/E ratio.

\section{METHODOLOGY}

This study was conducted by using secondary data, which means data that has been collected through primary sources and made available to be used. The type of data used are including company annual reports, financial statements, public expose, company updates, and press releases.

For the methodology, this study follows a systematic approach that starts from the business issue that was stated in the previous chapter. Followed by the external and internal analysis by using some frameworks to assess the position of KLBF in the competition as well as understanding its competitive advantage. PESTEL and Porter's Five Forces analysis were conducted to identify the external factors of the pharmaceutical industry. Business model canvas and industry benchmarking using financial ratio analysis were conducted 
to assess the internal condition of the company as it being compared to its industry peers. Lastly, SWOT analysis was conducted to get a better understanding of the overall company's business landscape.

Next, business valuation was conducted by using absolute and relative valuations in order to achieve the objective of the study. Absolute valuation was performed by using Discounted Cash Flow (DCF) model in order to determine the intrinsic value. Enhanced with the relative valuation that was performed using the industry average P/E and EV/EBITDA. The output of the calculation will be the underlying of the recommendation to BUY, HOLD or SELL.

\section{FINDINGS AND ARGUMENTS}

\section{A. Revenue Projection}

KLBF's total revenue was mainly generated from its four lines of businesses, which are nutritional, prescription pharmaceutical, consumer health, and distributions \& logistics. In projecting the revenue growth, the company's internal target for the year 2021 between 5-6\% is being used and aligned with the past five years' average of historical annual growth, which is $5.3 \%$. This growth rate then used for annual revenue growth in $2021 \mathrm{~F}$ to $2025 \mathrm{~F}$.

\section{B. Cost of Goods Sold}

KLBF's cost of goods sold was constructed mainly from imported medical raw material which composed for more than $90 \%$ of the cost structure. This creates a dependency on the supplier as well as an inability to manage the price. As for the projection of COGS, the approach used to calculate it was by using percentage to sales which were increasing in the last 5 years. Therefore, the latest COGS to sales percentage is used since it is least likely for the price to decrease in the future, which is $55.7 \%$ and is assumed to be constant in this study.

\section{Operating Expenses}

Selling expenses and G\&A expenses were projected by using the same approach with COGS which were calculated by using the percentage to sales, resulted in $21.7 \%$ and $6.0 \%$ respectively. For R\&D expenses, the assumption used was by calculating the average of the past five years $R \& D$ expenses to sales, which resulted in $1.2 \%$.

\section{Discount Rate}

The Weighted Average Cost of Capital (WACC) will be used as the discount rate to calculate the present value of expected Free Cash Flow to Firm (FCFF). WACC represents a firm cost of capital across all of its sources which is then weighted by its percentage of total capital and added together. There are several inputs required to calculate WACC, which were risk-free rate, beta of asset, market risk premium, country default spread and company default spread. The riskfree rate used was the 10 years government bond yield, which was $6.61 \%$. Beta of asset was obtained from Pefindo Beta Stock which was 1.093. The other inputs were obtained from Damodaran's country default spread and risks premium as well as the synthetic rating for company default spread, which resulted in $6.56 \%$ market risk premium, $1.68 \%$ country default spread, and $0.63 \%$ company default spread. Based on these inputs, the WACC of KLBF is $6.59 \%$.

\section{E. Terminal Growth}

In this study, the perpetuity method was used in order to calculate the terminal value of the company. This method assumes that the cash flows of the firm will grow at a constant rate forever. According to Damodaran, this constant rate cannot exceed the growth rate of the economy, but it can be set lower. Therefore, the terminal growth rate that used in this study is Indonesia's GDP growth rate in 2019 which is 5.02\%. This rate is believed to be reasonable considering that the average GDP growth rate for the Indonesia pharmaceutical industry is around $6.16 \%$.

\section{F. Absolute Valuation}

Based on the calculation using DCF method in this study, the intrinsic value of KLBF obtained is IDR 1,397 per share, which is lower by around $4 \%$ from the closing price on June 1st, 2021, of IDR 1,445 per share. According to this result, the stock market price is considered to be overvalued.

TABLE III: CALCULATION OF ABSOLUTE VALUATION

\begin{tabular}{cccc}
\hline \multicolumn{4}{c}{ Stock Valuation of KLBF (in bio IDR) } \\
\hline Enterprise Value & $71,999.992$ & ST Debt & 220.500 \\
Net Debt & $(6,593.921)$ & LT Debt & $1,111.492$ \\
Fair Value & $65,460.07$ & Cash & $5,207.929$ \\
Outstanding Shares & 46.873 & Net Debt & $(6,539.921)$ \\
Intrinsic Value per & 1,397 & Margin of & $-4.02 \%$ \\
$\quad$ Share & & Safety (\%) & \\
$\begin{array}{c}\text { Current Price (per 1 } \\
\text { Jun 2021) }\end{array}$ & 1,455 & & \\
\hline
\end{tabular}

\section{G. Relative Valuation}

The valuation was conducted by using the industry average of $\mathrm{P} / \mathrm{E}$ and EV/EBITDA ratio, then used as the basis to calculate KLBF's intrinsic value. The industry average in this study was constructed by using 5 pharmaceutical companies which composed of competitors and industry peers. The intrinsic value of KLBF found by using the average P/E ratio is IDR 1,233 per share, which is lower by $15.2 \%$ from the closing price of IDR 1,445 per share. Therefore, the stock market price is considered to be overvalued.

\begin{tabular}{ccccccc}
\multicolumn{7}{c}{ TABLE IV: RELATIVE VALUATION (P/E RATIO) } \\
\hline Entity & 2016 & 2017 & 2018 & 2019 & 2020 & $2021 \mathrm{~F}$ \\
\hline KLBF & 30.88 & 32.96 & 29.00 & 30.29 & 25.38 & 23.56 \\
SIDO & 15.99 & 15.20 & 18.76 & 23.52 & 25.65 & \\
MERK & 26.82 & 26.32 & 1.66 & 16.29 & 20.50 & \\
PYFA & 20.79 & 13.74 & 11.97 & 11.34 & 23.60 & \\
DVLA & 12.90 & 13.52 & 10.78 & 11.36 & 16.69 & \\
TSPC & 16.55 & 14.88 & 12.19 & 11.34 & 8.00 & \\
Industry & 20.66 & 19.43 & 14.06 & 17.36 & 19.97 & \\
Average & $-33.1 \%$ & $-41.0 \%$ & $-51.5 \%$ & $-42.7 \%$ & $-21.3 \%$ & $-15.2 \%$ \\
Delta & Relative Price (PER Comparison) & & $\mathbf{1 , 2 3 3}$ \\
\hline \multicolumn{7}{c}{}
\end{tabular}

While by using the average EV/EBITDA ratio, the intrinsic value of KLBF is at IDR 1,330 per share, which is lower by $8.6 \%$ from the closing price of IDR 1,445 per share. Therefore, the stock market price is considered to be overvalued. 
TABLE V: RELATIVE VALUATION (EV/EBITDA RATIO)

\begin{tabular}{ccccccc}
\hline Entity & 2016 & 2017 & 2018 & 2019 & 2020 & $2021 \mathrm{~F}$ \\
\hline KLBF & 20.4 & 19.2 & 18.5 & 19.5 & 15.8 & 14.2 \\
SIDO & 21.7 & 15.1 & 13.5 & 16.4 & 18.5 & \\
MERK & 17.5 & 62.8 & 29.0 & 7.5 & 14.0 & \\
PYFA & 7.0 & 5.4 & 5.9 & 5.5 & 17.1 & \\
DVLA & 6.5 & 6.6 & 6.0 & 6.1 & 9.2 & \\
TSPC & 8.4 & 7.8 & 5.3 & 4.5 & 3.3 & \\
Industry & 13.6 & 19.5 & 13.0 & 9.9 & 13.0 & \\
Average & $-33.4 \%$ & $1.4 \%$ & $-29.5 \%$ & $-49.2 \%$ & $-17.8 \%$ & $-8.6 \%$ \\
Delta & Relative Price (EV / EBITDA Comparison) & & $\mathbf{1 , 3 3 0}$ \\
\hline \multicolumn{7}{c}{}
\end{tabular}

\section{CONCLUSION AND RECOMMENDATION}

\section{A. Conclusion}

Based on the analysis performed in this study, it is showing that investors are having a high expectation and good perception towards the company which is driven by the company's good track record of financial performance and reputation. Moreover, the COVID-19 pandemic brought big opportunities that can be seen as a bright prospect for the company as it is currently on the brink of developing vaccines and medicine for COVID-19.

Nevertheless, despite the relatively overvalued price of the share, KLBF is still able to live up to its expectation by scoring positive growth in its profitability especially the net profit margin, which is also experienced by some of its competitors such as PYFA, SIDO, and TSPC. This is not absent from the opportunities presented by the increasing demand for healthcare products due to the change of consumer behavior and is expected to reach higher growth in the future.

This study conducted the valuation process by using the absolute and relative valuation method to find the intrinsic value of KLBF. The result of the valuation was consistently showing that the current price of KLBF per June 1st, 2021 of IDR 1,445 is overvalued. Absolute valuation using FCFF method was resulting an intrinsic value of IDR 1,397 per share $(4.02 \%$ lower). This result is supported by the intrinsic value found by using a relative valuation of $\mathrm{P} / \mathrm{E}$ average for IDR 1,233 per share (15.2\% lower) and EV/EBITDA average for IDR 1,330 per share ( $8.6 \%$ lower).

\section{B. Recommendation}

The recommendation will be addressed for investors who have an interest to invest their capital in Kalbe Farma amidst this COVID-19 pandemic. While the company possessed good prospects for its development of vaccines and drugs, the result of the analysis in the previous chapter will be the basis in providing the action recommendation.

According to the CFA's standard measurement, market value $15 \%$ below the intrinsic value will result in BUY recommendation, the market value between $15 \%$ below and above the intrinsic value will result in HOLD recommendation and market value above $15 \%$ the intrinsic value will result in SELL recommendation.

Absolute valuation displayed the market value is $4 \%$ above the intrinsic value, while the relative valuation of $\mathrm{P} / \mathrm{E}$ and EV/EBITDA displayed the market value is $15 \%$ and $9 \%$ above the intrinsic value respectively. Therefore, the final recommendation for the investor was to HOLD the KLBF stock.

\section{REFERENCES}

[1] M. Saragih, and T. Nurhaida, "The impact of the COVID-19 Pandemic on Stock Investment in the Indonesian Capital Market," Management Research and Behavior Journal, vol. 1, June 2021.

[2] M. Alanyali, "Quantifying the Relationship Between Financial News and Stock Market," Scientific Reports Nature Research, December 2013.

[3] M. Welley, and N.S. Franky, "The Comparison of State-Owned Pharmaceutical Stock Price Before and After COVID-19 Vaccine Development," JMBI UNSRAT, vol. 7, December 2020.

[4] Kalbe Farma. (2020, May 27). Kalbe Collaborates with Genexine of South Korea to Develop COVID-19 Vaccines [Press Release]. https://www.kalbe.co.id/news-andevents/ArtMID/443/ArticleID/825/Kalbe-Collaborates-withGenexine-of-South-Korea-to-Develop-COVID-19-Vaccines.

[5] D. Kahneman, and A. Tversky, "Prospect Theory: An Analysis of Decision Under Risk." Econometrica, vol. 47, March 1979.

[6] M. Porter, "How Competitive Forces Shape Strategy." Harvard Business Review, Vol. 57 No. 2, March 1979.

[7] P. Barnes, "The Analysis and Use of Financial Ratios: A Review Article." Journal of Business Finance \& Accounting, vol. 14, no. 4, December 1987.

[8] N. Singh, "SWOT Analysis - A Useful Tool for Community Vision." Concept Paper of Central Himalayan Village, Res 2 No. 9. 2010.

[9] Brigham, F. Eugene, and F. Houston, "Fundamentals of Financial Management $12^{\text {th }}$ edition." Mason: South-Western Cengage Learning. 2009.

[10] A. Thompson, A.J. Stickland, and J.E. Gamble, "Crafting and Executing Strategy-Concepts and Cases,

[11] S. Bhattacharyya, "Intrinsic Value of Share: A Conceptual Discussion." Journal of BS University of Calcutta, vol. 33-34, 2013.

[12] V. Ford. (2011, November 4). What is Intrinsic Value? Definition of Intrinsic Value. The Law Dictionary. https://thelawdictionary.org/intrinsicvalue/\#: :text=he $\% 20$ intrinsic $\% 20$ value $\% 20$ of $\% 20$ a,everywhere $\% 20$ and $\% 20$ to $\% 20$ every $\% 20$ one.

[13] J. Hampton, "Handbook for Financial Decision Makers." Reston Publishing Company, pp. 543-544. 1979.

[14] Annual Report. (2016-2020). PT Kalbe Farma Tbk.

[15] A. Damodaran. Country Default Spreads and Risks Premiums. 2021. [Online]. Available: http://pages.stern.nyu.edu/ adamodar/New_Home_Page/datafile/ctry prem.html.

[16] A. Damodaran. Growth Rate and Terminal Value. [Online]. 2006, Available:

http://people.stern.nyu.edu/adamodar/pdfiles/ovhds/dam2ed/growthan dtermvalue.pdf.

[17] A. Damodaran. It is all relative. Multiples, Comparable and Value. 2010. [Online]. Available: http://pages.stern.nyu.edu/ adamodar/pdfiles/country/relvalAIMR.pdf

[18] K. Brown, Reilly, and K. Frank. "Analysis of Investments and Management of Portfolios, $9^{\text {th }}$ edition. South Western Cengage Learning. 2009.

[19] K. Zelazowski, "Application of Multiple-Based Methods in Valuation of Real Estate.” Real Estate Management and Valuation, vol. 23, no. 3, 2015.

[20] A. Pandey, and S. Sehgal, "Equity Valuation Using Price Multiples: Evidence from India." Asian Academy of Management Journal of Accounting and Finance, vol. 6, no. 1, 2010.

[21] D. Inezwari, "Relative Valuation Model Analysis of IDX LQ45 Stocks." Journal of Applied Finance and Accounting, vol. 6, no. 1, 2013.

[22] E. Persson, A. Stahlberg, "P/E and EV/EBITDA Investment Strategies vs. the Market: A Study of Market Efficiency," Master Thesis, International Business Program., Linkoping University, Sweden, 2006.

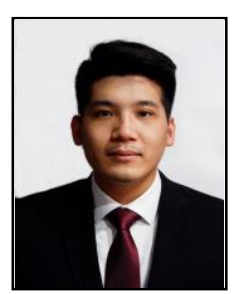

Gideon Ericko Setiawan was born in Jakarta, $14^{\text {th }}$ of June 1993. He earned his bachelor's degree in accounting from President University. He is currently pursuing his master's degree in Business Administration from School of Business and Management Institute of Technology Bandung (SBM ITB). He has work experience as a Finance Control Analyst in Astra International and currently working at Philip Morris International as a Financial Planning Analyst. 


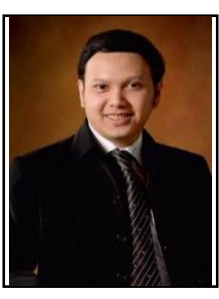

Dr. Erman Sumirat is currently a lecturer at the School of Business and Management Institute of Technology Bandung (SBM ITB). He is also a Certified Investment Banking, Certified Securities. Analyst (CSA) and Certified Risk Professional (CRP)

Research area that he focuses on include Corporate Finance, Business Risk Management, Economics, Islamic Banking, Islamic Finance, Financial Management and Capital Market. 